\title{
Tekst og ytringshandlingsteori
}

\author{
Kjell Lars Berge \\ I artikkelen presenteres det hvordan innsikter fra etablert tale- \\ handlingsteori kan anvendes og innlemmes i en utviklet tekstteori \\ der tekster forstås som kulturelt legitimerte meningskapende yt- \\ ringer i ulike situasjons- og kulturkontekster. I artikkelen vises \\ det hvordan talehandlinger - forstått som ytringshandlinger - er \\ innordnet i tre ulike globale tekststrukturelle mønstre: hiararkis- \\ ke og lineære strukturer, samt rammestrukturer. Det vises hvor- \\ dan ytringshandlinger forholdet seg til teksters flerstemmighet. \\ Artikkelen forholder seg første og fremst til tekstteoretiske og \\ -empiriske studier fra Norge og Norden, men diskuterer kortfattet \\ tilsvarende faglig utvikling i systemisk-funksjonell lingvistikk, i \\ den såkalte "Geneve"-skolen og retorisk strukturteori. I artikke- \\ len er de teoretiske resonnementene ledsaget av konkrete tekster \\ hentet fra autentiske ytringssituasjoner.
}

For 24 år siden - i 1986 - publiserte jeg en artikkel "Tekst og talehandlingsteori" (Berge 1986) i det nå nedlagte tidsskriftet Norskrift. Arbeidsskrift for nordisk språk og litteratur. I artikkelen tok jeg utgangspunkt i den da relativt nye fagdisiplinen tekstlingvistikk. Jeg (på-)viste hvordan talehandlingsteorien kan anvendes og utvikles for å utvikle en mer kompleks teori om tekst som handling, og hvordan tekster er bygd opp for å kunne mediere talehandlinger på en funksjonell og relevant måte. I denne artikkelen skal jeg følge opp presentasjonen og diskusjonen i artikkelen fra 1986, men supplere med innsikter om tekststruktur generelt og forholdet mellom tekststruktur og talehandlinger spesielt utviklet i tekstanalytisk arbeid i Norden og internasjonalt siden den gang. Jeg skal særlig ta utgangspunkt i en rekke arbeider publisert i norske tekstforskningsmiljøer (f.eks. Berge 1990, 2008, Hågvar 2003, Raddum \& Veum 2006, Tønnesson 2001, 2004) men kaste flere sideblikk til spesielt tre viktige internasjonale tekstvitenskapelig orienterte miljøer. Det gjelder for det første systematisk-funksjonell grammatikk (Halliday \& 


\section{Kjell Lars Berge}

Matthiessen 2004), for det andre den såkalte "Geneve-skolen" (Filliettaz \& Roulet 2002) og for det tredje såkalt "retorisk strukturteori" (Mann \& Thompson 1988). For en grundigere presentasjon og mer inngående og kompliserende diskusjon av forholdet mellom tekststruktur og talehandlinger, viser jeg til 1986-artikkelen.

I 1986-artikkelen, samt i en bok som forholdt seg til artikkelen (Berge 1988), la jeg til grunn at en forståelse av teksters strukturer må forholde til at en tekst er en meningsskapende ytring. En ytring er en kommunikativ handling. I så måte bidrar den til å skape og forme en kommunikativ hendelse. Som meningsskapende har ytringen to dimensjoner: Den uttrykker et saksforhold, og den bærer en spesifikk intensjonalitet. Det vil si at ytringen kan analyseres som både som en proposisjon, og som en talehandling - eller "ytringshandling". Siden artikkelen ble publisert, er det blitt mer vanlig å forstå "speech acts" som ytringshandlinger for nettopp å framheve det situasjonelle ved den kommunikative hendelsen. Jeg skal derfor bruke begrepet "ytringshandling" i resten av denne artikkelen.

Som ytring er den også mediert. Ytringen inngår som semiotisk fenomen en tegnfunksjon mellom et innholds- og et uttrykksplan. Selvsagt medieres tekster ofte verbalspråklig, men ikke nødvendigvis. En hvilken som helst seriøs teori om tekster (Berge 2008) må innarbeide at tekster medieres multimodalt. En naturvitenskapelig tekst for eksempel utnytter vanemessig andre semiotiske ressurser enn hverdagsspråk når tekster skal ytres i tekstkulturen (Knain 2001). Jeg skal vende tilbake til de utfordringene denne siste innsikten innebærer for analyse av tekststruktur.

Tekster er vanligvis utviklet for å kunne mediere begge disse meningsdimensjonene (Berge 1990). Som intersubjektivt tilgjengelig ytringshandling har en tekst ytre form (Berge 2008). Den utgjør en konfigurasjon som avgrenser den, og gjør den finitt. En tekst har en eller annen grense. For eksempel - men ikke nødvendigvis - kan den ha en begynnelse og en slutt. $\AA$ anta at tekster har lineære strukturer, er en vanlig forståelse i vår kultur, og i kulturer som anvender fonetisk skrift som representasjon i skriftlige tekster. I tilegg vil en tekst vanligvis - men ikke nødvendigvis - ha en indre struktur, en oppbygning som organiserer meningen i teksten både proposisjonelt og illokutivt; som saksforhold og som handling. ${ }^{1}$ 


\section{Tekst og ytringshandlingsteori}

Med utgangspunkt og en videreutvikling av Teun van Dijks begrep "makrostruktur" (van Dijk 1980) mente jeg i 1986-artikkelen at makrostrukturen i en tekst - forstått som en statisk og finitt størrelse - kunne beskrives fra to dimensjoner: et finitt antall proposisjoner og et finitt antall illokutivhandlinger. Antakelsen om at tekster har makrostrukturer, er forankret $\mathrm{i}$ at de er hierarkisk organiserte. Begrunnelsen for den antakelsen jeg sluttet med til i 1986, er knyttet til teorier om og empiriske undersøkelser av "cognitive processing": Når vi leser eller hører en tekst, behandler vi som forståelsesorienterte individer informasjon mentalt etter hvor viktig eller uviktig for en relevant forståelse av teksten informasjonen er, gjennom det van Dijk kaller "macro rules". Følgelig er det en rimelig antakelse at tekster er organisert og mediert slik at de gjør det mulig for den som skaper tekster, og den som forholder seg forstående til den, å markere - på en eller annen måte - $i$ den objektivt tilgjengelige ytringen hva som er overordnet og mest forståelsesrelevant og dermed "viktig" mening på den ene siden, og hva som er underordnet mening, og dermed mindre "viktig" for forståelsen, på den andre. ${ }^{2}$ Denne sannsynlighetsbaserte antakelsen eller innsikten tillater oss å anta to forhold:

For det første at tekster er organisert i en slags delbetydninger, det vil si meningsbiter eller, som jeg skal kalle dem, "betydningssegmenter".

For det andre at disse betydningssegmentene er fordelt hierarkisk etter hvor viktige de er for å etablere en relevant forståelse mellom den som ytrer teksten, og den som forholder seg forstående til den.

Vi kan altså hevde at tekster består av en slags betydningssegmenter, og at disse betydningssegmentene er byggesteinene i tekster. Hvilke egenskaper har så betydningsegmentene? Min idé i 1986 var - og er fortsatt - at hvert betydningssegment kan forstås som en ytringshandling. Disse ytringshandlingene kan forstås som handlinger med et illokutivt aspekt og med et proposisjonelt aspekt. Dessuten kan ytringshandlingene deles opp i handlinger som er overordnet andre handlinger, og handlinger som er underordnet de overordnede handlingene. Overordnede handlinger kan kalles "makrohandlinger, mens underordnede handlinger kan kalles "mikrohandlinger". Siden hver ytringshandling bærer en proposisjon, kan overordnede proposisjoner kalles "makroproposisjoner", mens underordnede proposisjoner kan kalles "mikroproposisjoner". La meg illustrere disse synspunktene med et eksempel, teksteksempel $1 .{ }^{3}$ 


\section{Kjell Lars Berge}

Uniformering og ensretting er begreper som vanskelig kan fylles med et entydig meningsinnhold. Jeg vil i det følgende knytte dem til tanker omkring indoktrinering, altså den prosess hvor normer regelmessig blir påført et individ uten individets bevisste medvirkning i innlæringen. Indoktrinering og ensretting er to sider av samme sak, der det siste er en konsekvens av det første. Begrepene, slik jeg vil bruke dem, opererer innen to forskjellige sfærer av et hele.

Som vi ser av teksteksempel 1, er denne teksten monomodal - i hvert fall er sekvensen som jeg har valgt å bruke som eksempel, det. Siden teksten er mediert i det grammatisk normerte skriftspråket (norsk)bokmål, kan vi forholde oss til dette skriftspråkets normer for hvordan ytringer skal medieres skriftspråklige for å gjelde som akseptable (Bartsch 1987). Det innebærer som normativt minimumskrav at ytringen på inneholde et ledd med funksjonen "subjekt" og et annet ledd som har funksjonen "finitt verbal”. Nå viser jo korpusorientert språkforskning at denne kvalifiseringsnormen statistisk sett ikke nødvendigvis følges (Itkonen 1983) ${ }^{4}$, men i vårt eksempel kan vi forutsette at den gjelder i hvert fall. Teksten ble i sin tid skrevet som oppgave (såkalt "stil") til den avsluttende morsmålseksamen i Norge i det som da het "gymnas". Dette var en viktig prøve i det norske skolesystemet, og markerte i sin tid overgangen fra skole til høyere studier. De ansvarlige myndigheter for gymnaset i Norge valgte i sin tid denne teksten ut som mønstergyldig for gode besvarelser (Berge 1985). Vi kan derfor ta for gitt at teksten følger skolens språk- og tekstnormer, så langt det er mulig for en 18-19år gammel skoleelev. Metodisk og tekstanalytisk får denne empiriske innsikten den konsekvensen for analysen at vi kan dele teksteksempel 1 opp i ytringer som oppfyller kravene til setninger, at de har subjekt og finitt verbal. Det gir oss følgende åtte ytringer i sekvensen:

1. Uniformering og ensretting er begreper

2. som vanskelig kan fylles med et entydig meningsinnhold

3. Jeg vil i det følgende knytte dem til tanker omkring indoktrinering

4. altså den prosess hvor normer regelmessig blir påført et individ uten individets bevisste medvirkning $\mathrm{i}$ innlæringen

5. Indoktrinering og ensretting er to sider av samme sak

6. der det siste er en konsekvens av det første

7. Begrepene, (...), opererer innen to forskjellige sfærer av et hele.

8. slik jeg vil bruke dem 
I denne typen tekster kan vi altså forutsette det M.A.K Halliday kaller "kongruens" mellom innholdsplanet - proposisjoner og handlinger - på den ene siden og uttrykksplanet, mediert hverdagspråk i skrift på den andre. Den innebærer at hver ytring kan forstås som en finitt setning og en handling med tilhørende proposisjon. Forholder vi oss til den lineære orden som den som har ytret teksten skriftlig, har valgt, kan denne tredelte analysen settes opp som en tabell. I figur 1, som iscenesetter tabellen, er proposisjoner forstått som transitivitetsprosesser etter analysetradisjonen i systematisk-funksjonell grammatikk (Halliday \& Matthiessen 2004) $)^{5}$.

\begin{tabular}{|c|c|c|c|}
\hline Segment & Setning & $\begin{array}{l}\text { Ytringshandling } \\
\text { (illokutiv) }\end{array}$ & $\begin{array}{l}\text { Prosess (propo- } \\
\text { sisjon) }\end{array}$ \\
\hline 1 & $\begin{array}{l}\text { Uniformering og ens- } \\
\text { retting er begreper }\end{array}$ & kvalifisering & relasjonell \\
\hline 2 & $\begin{array}{l}\text { som vanskelig kan } \\
\text { fylles med et entydig } \\
\text { meningsinnhold }\end{array}$ & kvalifisering & atferdsmessig \\
\hline 3 & $\begin{array}{l}\text { Jeg vil i det følgende } \\
\text { knytte dem til tanker } \\
\text { omkring indoktrinering }\end{array}$ & konstativ & relasjonell \\
\hline 4 & $\begin{array}{l}\text { altså den prosess hvor } \\
\text { normer regelmessig } \\
\text { blir påført et individ } \\
\text { uten individets bevisste } \\
\text { medvirkning i innlæ- } \\
\text { ringen }\end{array}$ & $\begin{array}{l}\text { konstativ (evt. } \\
\text { kvalifisering) }\end{array}$ & materiell \\
\hline 5 & $\begin{array}{l}\text { Indoktrinering og ens- } \\
\text { retting er to sider av } \\
\text { samme sak }\end{array}$ & kvalifisering & relasjonell \\
\hline 6 & $\begin{array}{l}\text { der det siste er en kon- } \\
\text { sekvens av det første }\end{array}$ & $\begin{array}{l}\text { konstativ (evt. } \\
\text { kvalifisering) }\end{array}$ & eksistensiell \\
\hline 7 & $\begin{array}{l}\text { Begrepene, }(\ldots), \text { ope- } \\
\text { rerer innen to forskjel- } \\
\text { lige sfærer av et hele. }\end{array}$ & kvalifisering & materiell \\
\hline 8 & slik jeg vil bruke dem & konstativ & materiell \\
\hline
\end{tabular}

Figur $1 \quad$ Linecer struktur i teksteksempel 1 og handlingstypene $i$ de ulike ytringshandlingene 
I denne analysen har jeg analysert de ulike ytringene som handlinger i samsvar med John Searles klassiske oppdeling av ytringshandlingsforekomster i typer i artikkelen "A taxonomy of illocutionary acts" publisert første gang i 1976 (Searle 1979). Alternative klassifikasjoner finnes, basert på andre prinsipper enn det sannhetsreferanseprinsippet ("direction of fit") som jo var så avgjørende viktig for den analytisk orienterte filosofen Searles måte å forstå ytringshandlinger på. Searles taksonomi består av følgende typer: "konstativer", "direktiver", "ekspressiver", "kommissiver" og de egentlige "performativene". Det vil si de ytringshandlingene der virkelighet skapes gjennom og ved ytringshandlingen. Imidlertid blir disse ytringshandlingene, som Austin i sin klassiske bok "How to do things with words" (Austin 1962) viet spesiell oppmerksomhet, uklart forstått i Searles taksonomi. Jeg har da supplert og nyansert Searles taksonomi med den norske juristen Nils Kristian Sundbys videreutvikling av taksonomien i boken "Om normer" fra 1978, der Sundby foreslår å kalle performativene for "kvalifiseringer". ${ }^{6}$

Med denne utvidelsen av Searles modell in mente ser vi at Searles ytringhandlingsklassifikasjon på en relevant og passende måte kan anvendes på tekster av den typen vi har å gjøre med i teksteksempel 1: klassifiserende tekster preget av tekstnormer utviklet i teknokratisk og samfunnsvitenskapelig litteratur. I denne typen tekster er begrepsdefinisjoner viktig, samt henvisninger til etablert viten, gjerne det som kalles "forskningsbasert" kunnskap. Men en slik kontekstuelt forankret tekstnormforståelse (Berge 1990) på plass er vi også i stand til å gjennomføre en analyse av hvordan meningen ikke bare er organisert lineært, men også hierarkisk. Den konvensjonelle skriftspråklige medieringen gir oss uten videre den fortløpende lineære strukturen, mens den hierarkiske strukturen forutsetter en kontekstuelt informert tolkning der forståelsen av teksten på den ene siden og forståelsen av situasjons- og kulturkonteksten på den andre sammenholdes. Den hierarkiske fordelingen av de ulike segmentene i makro- og mikrohandlinger framgår av figur $2:^{7}$ 


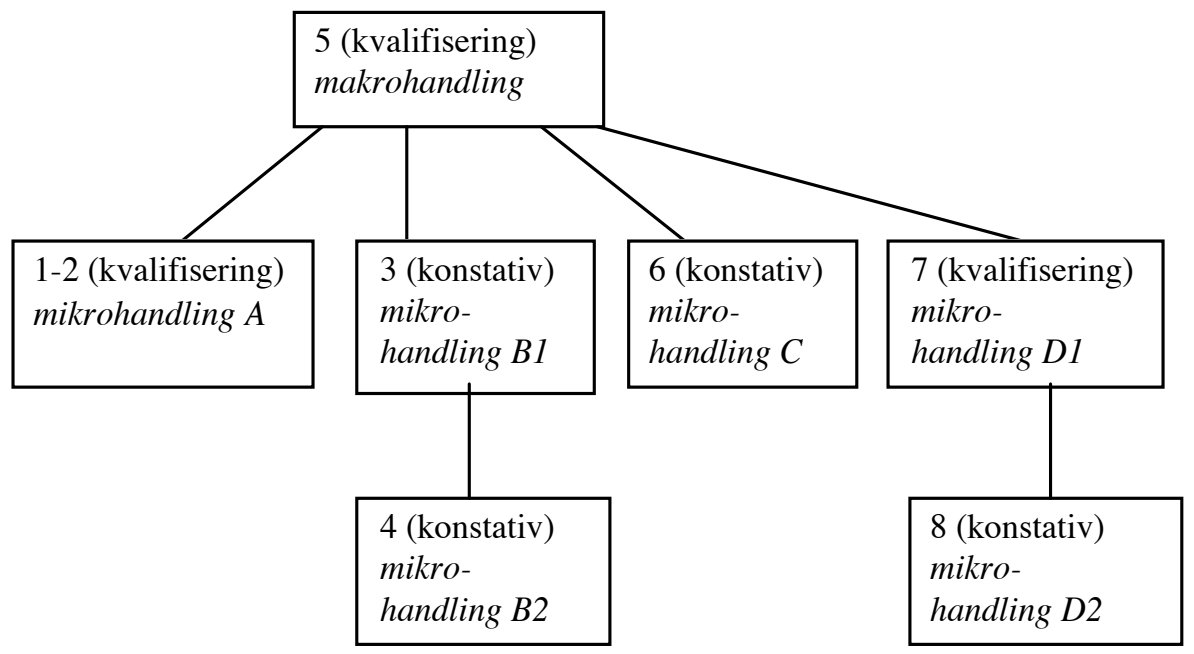

Figur 2 Hierarkisk struktur i teksteksempel 1 og handlingstypene i de ulike makro- og mikrohandlingene

Forstått hierarkisk slik figur 2 artikulerer gjennom illustrasjonen, kan vi lettere analysere teksten som dynamisk sekvens av mer eller mindre underst $\varnothing t t e n d e$ meningsskapende ytringshandlinger. Teksten utfolder seg i skapelses- og tilegnelsesprosessen som en innledende definisjonshandling (mikrohandling A) som forankres på samme informasjonsnivå (nivå 2) med en konstatering basert på (antatt?) samfunnsvitenskapelig tradert kunnskap om hva sosialisering er (mikrohandling B1,2), før det nås en overordnet definisjon (dvs. en kvalifisering, 5) av forholdet mellom kategoriene "ensretting" og "indoktrinering" (makrohandlingen). Definisjonen i makrohandlingen i segment 5 skal bestemme utviklingen av den indre strukturen i de andre sekvensene i teksten (utdraget vårt er altså den første sekvensen). ${ }^{8}$ Derfor må denne ytringshandlingen anses som førende for leserens forståelse. Dette er den ytringshandlingen som den som forholder seg forstående til teksten ("leseren"), må forstå på en relevant måte dersom tekstens mening skal tolkes i samsvar med ytrerens intensjonalitet. Dernest beskrives forholdet mellom de to kategoriene. Alternativt kan relasjonen forstås som nok en kvalifisering. Når den etterfølgende ytringshandlingen, mikrohandling D1 (segment 7), blir forstått som kvalifiserende, og ikke som en beskrivende konstativ, er det fordi ytreren i mikrohandling D2 (segment 8), understreker at dette er ytrerens spesielle anvendelse/bruk. Jeg tolker denne forståelsen som en gyldig kvalifisering for hele den teksten som ytreren er i ferd med å skape. 


\section{Kjell Lars Berge}

Den sveitsiske tekstlingvisten Eddy Roulet (Filliettaz \& Roulet 2002) bruker begrepet "monologiske tekster" for å vise til tekster med én og bare én makrohandling. Tekster med mer enn én makrohandling blir i hans tekstteori kalt "dialogiske". Sekvensen vi har analysert, er derfor å forstå som monologisk, men siden den samlet inngår som en tekstsekvens (segmentene 1-8) som utgjør én makrohandling sammen med andre sekvenser med hver sin makrohandling, kan hele teksten som sekvensen vi har analysert så langt er innledningen til, betraktes som det Roulet kaller en "dialogisk" tekst.

Så langt har vi altså sett at en tekst avgrenset (ytre form) og som en finitt mengde ytringshandlinger (indre struktur) kan bli skapt og forstått med utgangspunkt i to ulike strukturelle organiseringsprinsipper: lineær struktur og hierarkisk struktur. Vi skaper mening forløpende gjennom å handle gjennom språket. Samtidig organiserer vi disse handlingene slik at det er mulig for den som skal forholde seg forstående til ytringene, å skille mellom overordnede og underordnede ytringshandlinger. Makrohandlingen er den overordnede ytringshandlingen som inneholder den proposisjonen som gir tilgang til tekstens bærende tema. Enda mer avgjørende er det at makrohandlingen gir tilgang til tekstens eller tekstsekvensens relevante intensjonalitet. Tekstens analytiske tolkningsvaliditet er derfor avhengig av at vi er i stand til å forstå hva som er makrohandlingen i monologiske tekster eller makrohandlingene i dialogiske tekster (Berge 2008). I det siste tilfellet er altså makrohandlingene sideordnede. Makrohandlingene er i dialogiske tekster likeverdige.

Fordi tekster er representasjoner av mening som i prinsippet skal være intersubjektivt tilgjengelig, kan teksters ytre form og indre strukturer analyseres og avdekkes slik vi så langt har sett et eksempel på. Vi skal nå se på et tredje overordnet tekststrukturerende prinsipp som er viktig ha innsikt i for å utvikle en fullgod forståelse av tekster som ytringshandlinger og kommunikative hendelser. Dette struktureringsprinsippet har jeg basert på en idé utviklet av Gregory Bateson (Bateson 1972, Berge 1990,1991) valgt å kalle "rammestruktur". Jeg har så langt vist at tekster kan forstås som fortløpende sekvenser av ytringshandlinger som samlet eller hver for seg må forstås som hierarkisk organiserte. Ved å ta i bruk innsikten om rammestrukturer er det mulig for oss å vise hvordan ulike ytringshandlinger kan veves inn i hverandre. Ytringshandlingene kan utgjøre selvstendige ytringer innarbeidet $\mathrm{i}$ andre ytringshandlinger. Det innebærer at makrohandlinger kan være innrammet av, og inngå i, andre makrohandlinger. Makrohandlingene inneholder, som nevnt flere 


\section{Tekst og ytringshandlingsteori}

ganger, de proposisjonene og illokutivene (intensjonalitetene) som ikke kan overses at den som forholder seg forstående til ytringen, dersom ytringen skal kunne forstås relevant. Dette fenomenet er i dag kjent under navnet "flerstemmighet" (Tønnesson 2001, Raddum og Veum 2006). I systemisk-funksjonell grammatikk er fenomenet kjent som "projisering" (Halliday \& Matthiesen 2004). Jeg skal i denne artikkelen omtale flerstemmighet som en trekk ved ytringen som gjør det mulig med innrammende og innrammede, men likevel selvstendige, makrohandlinger i en og samme avgrensede og finitte tekst eller tekstsekvens.

Neste eksempel (teksteksempel 2) er en svensk tekst. Teksten utgjør det samlede forordet til en svensk håndbok med tittelen " $\mathrm{ABC}$ om bostaden" (Strömblad 1988). Utgiver av boken er organisasjonen HSB:s riksförbund, en svensk boligkooperasjon som leier ut leiligheter på et ideelt og ikke-kommersielt grunnlag. Boken ble i sin tid gitt til alle som leide en leilighet av dette utleieselskapet:

(1) Tanken med den här skriften är att den ska fungera som en handbok. (2) Här kan du läsa om det mesta som har med bostaden att göra.

(3) I inledningsavsnittet har vi samlat en del tips (4) som rör själva flyttningen. (5) I olika avsnitt berättar vi sedan (6) hur saker och ting i lägenheten fungerar (7) och hur man enklast klarar skötsel och underhåll. (8) Även om fastighetsskötaren gärna hjälper till (9) är det praktisk att kunna utföra vissa saker själv i bland.

(10) I innehållsförteckningen kan du ser i mer detalj (11) vad de olika avsnitten handlar om. (12) För att det ska vara lätt att hitta (13) finns det även ett sakregister.

(14) Längst bak hittar du en adress- og telefonlista (15) där du kan anteckna alla telefonnummer (16) som är aktuella (17) när det gäller din bostad och ditt bostadsområde. (18) Där finns också en minneslista för sådant (19) som rör bostaden.

(20) Förvara ABC om bostaden på nogot lättillgängligt ställe (21) så att den alltid finns till hands när du behöver den.

Teksteksempel 2 er en typisk byråkrati- eller organisasjonstekst. Den er en slags redskapstekst som først og har fremst har en instrumentell nytteverdi innenfor en relativt spesifisert sammenheng. Slike teksters oppgave som ytringshandlinger er å klassifisere og organisere. Ved hjelp av dem kan arbeidsoppgaver for byråkratiets tjenestemenn og -kvinner 


\section{Kjell Lars Berge}

fordeles. Tekster av denne typen gir forskrifter som bidrar til å strukturere hverdagslivet til vanlige mennesker. Når det gjelder "ABC om bostaden" spesielt, er bokens overordnede oppgave å vise leietakeren hva slags forpliktelser leietakeren og utleier har i forhold til hverandre. Som en henvendelse fra en stor organisasjon som leier ut husrom til leietakere, er teksten følgelig en tekst der hensikten med ytringshandlingen - den perlokutive dimensjonen ved ytringshandlingen (for å holde oss til ytringshandlingsteorien slik vi kjenner den fra Searle) - er at den som leier ut, vil få leietakeren til å gjøre noe som vedkommende ellers ikke ville gjort. Men teksten eksemplifiserer også en type tekst der en samfunnsinstitusjon med mye formell makt (HSB:s riksförbund) fors $\varnothing$ ker å forhandle om det asymmetriske forholdet den står i til en ganske svakt posisjonert leser: leietakeren. Denne sammensatte hensikten med teksten stiller store krav til leserens forståelse av den. Hva tekstens overordnede ytringshandlinger er, er i dette tilfellet tatt for gitt på en måte som forutsetter stor innsikt i kulturelle normer for svensk hverdagsliv i såkalte "hyreshus". Teksteksempel 2 skal altså løse flere ulike oppgaver samtidig. Det innebærer at vi kan anta at teksten vil ha flere ulike makrohandlinger. Og som vi altså skal se, løses oppgaven ved at det konstituerende trekket $\mathrm{i}$ teksten er rammestruktur. La oss prøve å visualisere hvordan de ulike makrohandlingene i teksten inngår i forskjellige rammestrukturer:

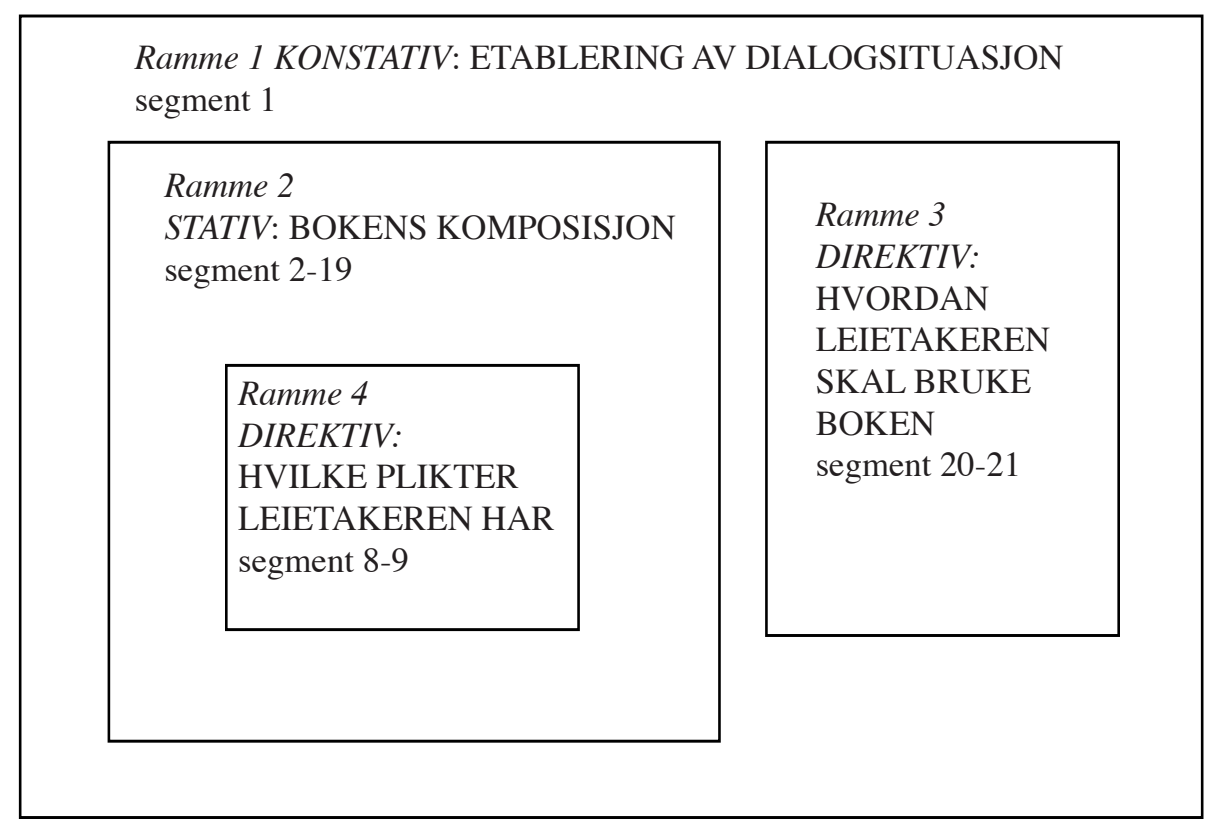

Figur 3 Rammestruktur i teksteksempel $2 \mathrm{og}$ ytringshandlingstypene i de ulike rammene 


\section{Tekst og ytringshandlingsteori}

Tekstanalysen av tekstens handlinger slik den er oppsummert i figur 3, baserer seg på den antakelsen at tekstens konstituerende globale organiseringsprinsipp er rammestrukturen. ${ }^{9}$ På samme måte som teksten i kraft av være forord rammer inn hele boken "ABC om bostaden", og dermed gir leseren nøkkelen til den relevante forståelsen av hele boken, fungerer det første segmentet i teksteksempel 2 (altså forordet) som ytringen der det etableres en dialogsituasjon mellom ytreren og den antatt kompetente leseren som ytreren forholder seg til. Segment 1 som bestemmer dialogsituasjonen, er altså den kvalifiserende ytringshandlingen: "Tanken med den här skriften är att den ska fungera som en handbok." Proposisjonen i ytringshandlingen forteller den antatt kompetente leseren, hva som er den relevante forståelsen av teksten: at "ABC om bostaden" er en "handbok" - hva nå det enn er!

Inne i ramme 1 finner vi to sideordnede rammer (ramme 2 og 3), med to ulike makrohandlinger. Ramme 2 inneholder segmentene fra 2 til 19, og omtaler hvordan "ABC om bostaden" er bygd opp. Makrohandlingen er konstativ. Ramme 3 som inneholder segmentene 20 og 21, forteller leseren at boken alltid skal være tilgjengelig. Makrohandlingen er et direktiv. Ytreren krever at leietakeren som leser boken, skal ta boken i bruk.

Inne i ramme 2 - der proposisjonene omtaler bokens komposisjon - finner vi ytterligere én ramme, ramme 4 . Ramme 4 inneholder segmentene 8 og 9. Hva er så makrohandlingen i denne rammen? "Även om fastighetsskötaren gärna hjälper till, är det praktisk att kunna utföra vissa saker själv i bland", står det.

Hva er den relevante forståelsen av denne makrohandlingen? For det første er proposisjonen at vaktmesteren gjerne hjelper til. Samtidig er proposisjonen at det er praktisk å kunne visse ting selv. Sammenholdt med ramme 3 som teksten avsluttes med - den med at boken skal være litt tilgjengelig, slik at du alltid finner den når du trenger den - i tillegg til at man holder i en tykk bok som har med vedlikehold og bruk av en leilighet, er en relevant forståelse av segmentene i ramme 4 at man ikke skal springe til vaktmesteren i tide og utide. Man skal faktisk holde leiligheten ved like selv, ved hjelp av "ABC om bostaden" som følger gratis med leiligheten. Ytringshandlingen i rammen blir dermed direktivet man som leietaker har plikt til å holde leiligheten ved like. Det er det man har "ABC om bostaden" til. Leietakeren skal altså ikke springe til vaktmesteren uten videre. Ytreren stiller et spesifikt krav til den relevante leseren i ytringshandlingen. 
Makrohandlingene i ramme 1 og ramme 2 - kvalifiseringen og konstativen - begge markert direkte i teksten. Men interessant nok er makrohandlingene i ramme 3 og 4 indirekte (Searle 1979). Man må altså lese teksten kontekstuelt sensitivt og informert for å skjønne at intensjonaliteten i makrohandlingene i begge rammer er direktivisk. Den som skriver, setter i ramme 3 og 4 fram krav til leseren. I teksteksempel 2 er ytringshandlingene (makrohandlingene i ramme 3 og 4) som er grunnleggende for at det dialogiske forholdet mellom modellsender og modellmottaker kan etableres, så å si pakket inn og gjemt bort i tekstens indre rammer. Og det kan legges til at språket er utnyttet slik at det som er innholdsmessig (eller semantisk) overordnet, er grammatisk underordnet. Det er altså ikke kongruens mellom setningsnivået, ytringshandlingens illokusjonære dimensjon og proposisjonen.

Hva er så det flerstemmige med denne teksten? Det flerstemmige består $\mathrm{i}$ at teksten i ulike rammer iscenesetter ulike samtalesituasjoner der ulike aktører henvender seg til hverandre på ulike måter og i ulike ytringshandlinger. I pressetekster (Raddum \& Veum 2006, Hågvar 2003) er dette et innarbeidet og strengt normert trekk. Ulike kilder gis rett til å ytre seg indirekte eller direkte. I vitenskapelige tekster kan forskere med ulike oppfatninger komme til orde og ytre seg på et selvstendig grunnlag, innrammet av en kommenterende forskers stemme (Tønnesson 2001). I vårt tilfelle har ytreren valgt å pakke inn viktige direktiviske krav til leseren inne i tekster der bokens innhold beskrives konstaterende. Denne litt forsiktige og konfliktunnvikende måten å organisere teksten på kunne selvsagt blitt løst opp dersom forfatteren har valgt å ytre de direktiviske makrohandlingene i egne tekstsekvenser lineært i teksten. I så fall ville ikke tekstens konstituerende globale tekststruktur vært en rammestruktur, men en lineær struktur med varierende hierarkisk oppbygning. ${ }^{10}$ Eddy Roulet kaller denne typen innrammende tekster som teksteksempel 2 illustrerer, for "dialogistiske" (Filliettaz \& Roulet 2002). "Monologistiske" tekster har bare én ramme som konstitueres i med tekstens ytre form.

Jeg slutter presentasjonen av forholdet mellom tekststruktur og ytringshandlinger her. Vi har sett at en tekst samlet må forstås som en kommunikativ handling. Tekstens ytre form utgjør en ytringshandling som konstituerer en kommunikativ hendelse. Dessuten kan tekstens indre struktur forstås som en finitt antall ytringshandlinger relatert til hverandre med ulik status som henholdsvis makro- og mikrohandlinger. Ma- 


\section{Tekst og ytringshandlingsteori}

krohandlingene må forstås av den teksten forholder seg til som forstående (mottakeren, leseren osv.), dersom tekstens mening skal tilegnes på en måte som er relevant for tekstens intensjonalitet(-er). Tekstens mening utgjøres av proposisjonene i ytringshandlingene. Intensjonalitetene i ytringshandlingene kan artikuleres gjennom ytringshandlingenes illokusjonære dimensjoner, grammatisk i såkalte "performative verb" (Engh 1977). Makrohandlingene vil alltid være enten lineært organisert, hierarkisk organisert eller organisert ved hjelp av rammestrukturer. Til hver makrohandling kan det knyttes ingen eller flere mikrohandlinger. Til makrohandlingen i rammetekst 2 er det knyttet 14 mikrohandlinger. Til makrohandlingene i ramme 3 og 4 er det kun knyttet én mikrohandling. I ramme 3 er det segment 8. I ramme 4 er det segment 20.

For denne typen forståelse av teksters strukturer oppstår det flere teoretiske utfordringer. Og det må også nevnes at framstillingen som er gitt $\mathrm{i}$ denne artikkelen når det gjelder tekststruktur, ikke på noen måte er uttømmende (Berge 1990). Av hensyn til denne artikkelens overordnede tematikk skal jeg nevne spesielt tre utfordringer som er særlig interessante.

Utfordring 1: Den første utfordringen i studiet av forholdet mellom tekst og ytringshandlinger har med det såkalte kongruensforholdet mellom innholdsplanet (illokusjonær kraft og proposisjonelt innhold i ytringshandlingen) og uttrykksplanet (grammatisk mediering) å gjøre. Som vi så av teksteksempel 2, var det ikke-kongruens i to av tekstens makrohandlinger. Det er da også svært mange år siden at det ble påpekt av blant andre Engh ${ }^{11}$ at forholdet mellom ytringshandlingen som semantisk-pragmatisk kategori og språket som grammatisk ressurs er problematisk. Innenfor det tekstlingvistiske paradigmet som denne artikkelen forholder seg til, er det svært få som har tatt opp kongruens, grader av kongruens og ikke-kongruens på en tilfredsstillende måte. Noen unntak er Matthiesen \& Thompson 1988 og Mann, Matthiessen, and Thompson 1992. En ekstra utfordring skaper - som nevnt - såkalt multimodalitet i tekster (Kress \& van Leuwwen 1996). I mange etablerte genrer vil makrohandlingen i tekster kunne være uttrykt i andre modaliteter i hverdagsspråk. Slik er for eksempel de konstaterende sekvensene i høy spesialiserte tekniske arbeidsbeskrivelser og rapporter ofte uttrykt visuelt (se f.eks. Knain 2001). Seriøs tekstvitenskap må forholde seg til multimodalitet som et konstituerende trekk i tekster. Ikke minst utviklingen av nettekster forsterker denne tendensen. Tekstviten- 
skapen må derfor ta inn over seg innsikter fra andre semiotisk orienterte fagdisipliner enn lingvistikken.

Utfordring 2: Den andre utfordringen følger av den første. Som vi sett av mine analyser av både teksteksempel 1 og 2, kreves det kunnskap om situasjons- og kulturkontekst for å forstå hvordan tekstene er bygd opp strukturelt, og dermed på en relevant måte kunne avgjøre hva som er makro- og mikrohandlinger i teksten. Det innebærer at tekstvitenskapen må innarbeide innsikter fra diskursanalysen. Denne innsikten igjen tilsier at det metodiske repertoaret som en tekstforsker bør forholde seg til og kunne anvende, utvides med metoder som ofte kjennetegner vitenskaper som sosiologi og antropologi. Ved å bruke disse vitenskapenes deltakerorienterte metoder, kan tekstforskeren få tilgang til forståelsene som gir innsikt i relevant tolkning av tekstene, dvs. hva som i tekstkulturen (Berge 2008) er de relevante bruksforståelsene av tekstene man studerer og analyserer. Bare ved å tilgang til slik - ofte innforstått - deltakerkunnskap, kan tekstenes makrohandlinger utvendiggjøres på en valid måte.

Utfordring 3: Den tredje utfordringen har jeg allerede vært inne på. Tekstlingvistiske analyser og representasjonene av dem slik vi har presentert dem i figurene 1-3, framstår som statiske størrelser, en slags krystaller i klassisk strukturalistisk utforming. Men tekst skapes og brukes som dynamiske og interaktive fenomener, akkurat som hverdagslige samtaler. Og det er nettopp fra den etnometodologisk orienterte samtaleforskningen, at den meste solide kritikken mot Searles taksonomier og deres anvendelse i forståelsen og analysen av ytringer, har kommet (Searle, Parret \& Verschueren 1992, Linell 1998). En mer dynamisk teori som på en eksplisitt måte drøfter tekster som ytringshandlinger, er den såkalte "Rhetorical Structure Theory" (Mann \& Thompson 1988). ${ }^{12}$ I denne teorien er alle ytringshandlinger gitt mening som dynamiske interaktive handlinger. Imidlertid er teorien kun utviklet for hierarkiske strukturer. Dessuten er konstrueres teorien induktivt ved at nye ytringshandlinger (retoriske strukturer) utvikles på grunnlag av tekster og genrer som suksessivt analyseres. Teorien har derfor ennå ikke et tilfredsstillende generaliseringspotensial. En tredje svakhet er at alle ytringer forstås innenfor rammene av en klassisk retorisk kommunikasjonsmodell (Berge 1994) der ytringshandlinger tolkes som persuasive. 


\section{Tekst og ytringshandlingsteori}

\section{Noter:}

1 I forskningen på hvordan barn lærer seg å ytre tekster i kulturen, er det viktig å skille mellom det å kunne ytre tekster konfigurativt på den ene siden og strukturelt på den andre. Svake skrivere i norsk skole har utviklet ferdigheter i å ytre tekster konfigurativt, men ofte med dårlig utviklet indre tekststruktur (Berge 2005).

2 Selvsagt kan en hvilken som helst mulig leser lese teksten slik han eller hun måtte $\varnothing n s k e$. Antakelsen hviler på den forutsetning at ytrer forholder seg til en leser eller lytter som er stand til å lese eller lytte teksten relevant, eller - dersom det ikke er tilfellet - kan utvikles som relevant leser/lytter gjennom måten teksten er bygd opp på. Denne teorien om "modell"-lesere eller-lyttere er opprinnelig utviklet av den italienske semiotikeren Umberto Eco, men videreutviklet av Johan Tønnesson ved Universitetet i Oslo (Tønnesson 2004)

3 Teksteksempel 1 er analysert inngående i Berge 1985, 1986.

4 Det innebærer at ytringer av typen "jasså", "javel", "aha" osv. ikke blir akseptert av tekstsnormforvalterne.

5 En slik analysemodell ble ikke brukt i 1986-artikkelen. Tradisjonell logisk orientert proposisjonsanalyse er så langt jeg kjenner til det, ikke tilfredsstillende for å analysere proposisjonsdelen av ytringshandlinger i tekster. En avansert semantisk forståelse av ytringers proposisjoner er derimot utviklet i systemisk-funksjonell grammatikk (SFL) For øvrig er SFL en av få grammatiske tradisjoner og teori som åpner for den direkte samhandling mellom setningsorientert grammatikk og tekstlingvistikk.

6 Sundby samarbeidet med Searle, og var involvert i diskusjonene rundt utviklingen av ytringshandlingstaksonomien. Sundbys begreper er de vanlige i norsk tekstvitenskap, og er derfor brukt i artikkelen. For en inngående diskusjon av ulike ytringshandlingstaksonomier, se Berge 1990.

7 Jeg slutter meg ikke til van Dijks psykologiske tekstlingvistikk her, men forholder meg til teksten og ytringen som intersubjektivt tilgjengelige artefakter. For tekster som forholder seg til tekstnormer som i eksempelet, innebærer det at vi kan forutsette (normativt) at én eller flere finitte ytringer i teksten kan forstås som makrohandlingen eller makrohandlinger. Tekstens ytre form og indre struktur kan dermed rekonstrueres som statisk.

8 For en uttømmende analyse av teksten, se Berge 1986.

9 Selvsagt kan teksten også analyseres som lineær struktur og hierarkisk struktur, men det tar jeg ikke opp her. Teksten er analysert og diskutert innenfor rammene av en diskusjon om tekst, språk og makt i Berge 2003.

10 Ramme 2 har en oppfattende hierarkisk oppbygging med et stort antall proposisjoner. Meningstettheten er i motsetning til i de andre rammene svært høy. 


\section{Kjell Lars Berge}

11 Se Berge 1986 for en inngående drøfting.

12 Teorien har også et meget godt nettsted: http://www.sfu.ca/rst/index.html (per 1.2.2010).

\section{Litteratur:}

Austin, John L. (1962). How to do things with words. Clarendon.

Bartsch, Renate (1987). Norms of language: theoretical and practical aspects. Longman.

Bateson, Gregory (1972). "A theory of play and fantasy”. I: Steps to an Ecology of Mind. Ballantine books:177-193.

Berge, Kjell Lars. (1985). Artiumsstilen som genre. Analyse av en form for kommunikativ atferd. Hovedoppgave i nordisk språk og litteratur. Universitetet i Oslo.

Berge, Kjell Lars (1986). “Tekst og talehandlingsteori”. I: Norskrift. 49. Universitetet i Oslo:24-63.

Berge, Kjell Lars (1988). Skolestilen som genre. Med påvtungen penn. Cappelen.

Berge, Kjell Lars (1990). Tekstnormers diakroni. Noen ideer til en sosiotekstologisk teori om tekstnormendring. MINS, Institutionen för nordiska språk. Stockholms universitet.

Berge, Kjell Lars (1991). "Samtalen mellom Einar og Reiar. Et symptom på tekstnormendringer i 1700-tallets skriftkultur?” I: Arkiv för nordisk filologi. 106:137-163.

Berge, Kjell Lars (1994). "Communication”. I: Concise Encyclopedia of Philosophy of Language. Pergamon Press:95-102.

Berge, Kjell Lars (2003). “Hvor er makten i teksten?” I. K.L. Berge, S. Meyer \& T.A. Trippestad (red.). Maktens tekster. Gyldendal Akademisk:24-41.

Berge, Kjell Lars (2005). "Tekstkulturer og tekstkvaliteter" I. K.L. Berge, L.S. Evensen, F. hertzberg \& W. Vagle (red.). Ungdommers skrivekompetanse. Norskeksamen som tekst. Bind II. Universitetsforlaget:11-190.

Berge, Kjell Lars (2008). “Teksten”. I. Asdal, Berge, Gammelgaard, Jordheim, Rem, Riiser-Gundersen \& Tønnesson. Tekst og historie. Universitetsforlaget:33-67.

Engh, Jan (1977). "Talehandlingsteori og språkbeskrivelse. Et oversyn”. I: Norskrift 13:44-77. 


\section{Tekst og ytringshandlingsteori}

Filliettaz, Laurent \& Eddy Roulet (2002). "The Geneva Model of discourse analysis: an interactionist and modular approach to discourse organization." I: Discourse Studies. Vol 4(3):369-393.

Halliday, M. A. K. and Christian Matthiessen (2004). An Introduction to Functional Grammar. Hodder Arnold Publication

Hågvar, Yngve (2003). Hele folkets diskurs. Sakprosa. 7. Universitetet i Oslo.

Iktonen, Esa (1983). Causality in linguistic theory: A critical inquiry into the philosophical and methodological foundations of 'non-autonomous' linguistics. Croom Helm.

Knain, Erik (2001). Naturfagets tause stemme. Sakprosa. 4. Universitetet i Oslo.

Kress, Gunther \& Theo van Leeuwen (1996). Reading Images: The Grammar of Visual Design. Routledge.

Linell, Per (1998). Approching dialogue. Talk, interaction and contexts in dialogical perspectives. IMPACT: Studies in Language and Society 3. John Benjamins.

Mann, William C., Christian M.I.M. Matthiessen \& Sandra A. Thompson (1992). "Rhetorical Structure Theory and Text Analysis." I: William C. Mann \& Sandra A. Thompson, eds., Discourse Description: Diverse Analyses of a Fund Raising Text. John Benjamins:39-78.

Mann, William C. \& Sandra A. Thompson (1988). "Rhetorical Structure Theory: Towards a Functional Theory of Text Organization". I: Text 8.3:243-281

Matthiessen, Christian \& Sandra A. Thompson (1988). The Structure of Discourse and 'Subordination'. I: John Haiman \& Sandra A. Thompson, eds. Clause Combining in Grammar and Discourse. John Benjamins:275-329.

Raddum, Tonje \& Aslaug Veum (2006). “Avistekstens mange stemmer”. I: Norsk Medietidsskrift. 13(2):135-158.

Searle, John R. (1969). Speech Acts, An Essay in the Philosophy of Language. Cambridge University Press.

Searle, John R. (1979). Expression and Meaning: Studies in the Theory of Speech Acts. Cambridge University Press

Searle, John R., Herman Parret \& Jef. Verschueren (1992). (On) Searle on Conversation. Pragmatics \& Beyond New Series 21. John Benjamins.

Strömblad, Görel. (1988) ABC om bostaden. HSB:s riksförbund.

Sundby, Nils Kristian. (1978) Om normer. Universitetsforlaget. 


\section{Kjell Lars Berge}

Tønnesson, Johan (2001). Vitenskapens stemmer. Sakprosa. 2. Universitetet i Oslo.

Tønnesson, Johan (2004). Tekst som partitur eller Historievitenskap som kommunikasjon: Narlesning av fire historikertekster skrevet for ulike lesergrupper. Unipub.

van Dijk, Teun (1980.) Macrostructures: An interdisciplinary study of global structures in discourse, interaction, and cognition. Erlbaum.

Kjell Lars Berge

Professor i tekstvitenskap

Institutt for lingvistiske og nordiske studier, Universitetet i Oslo

E-post: k.1.berge@iln.uio.no 